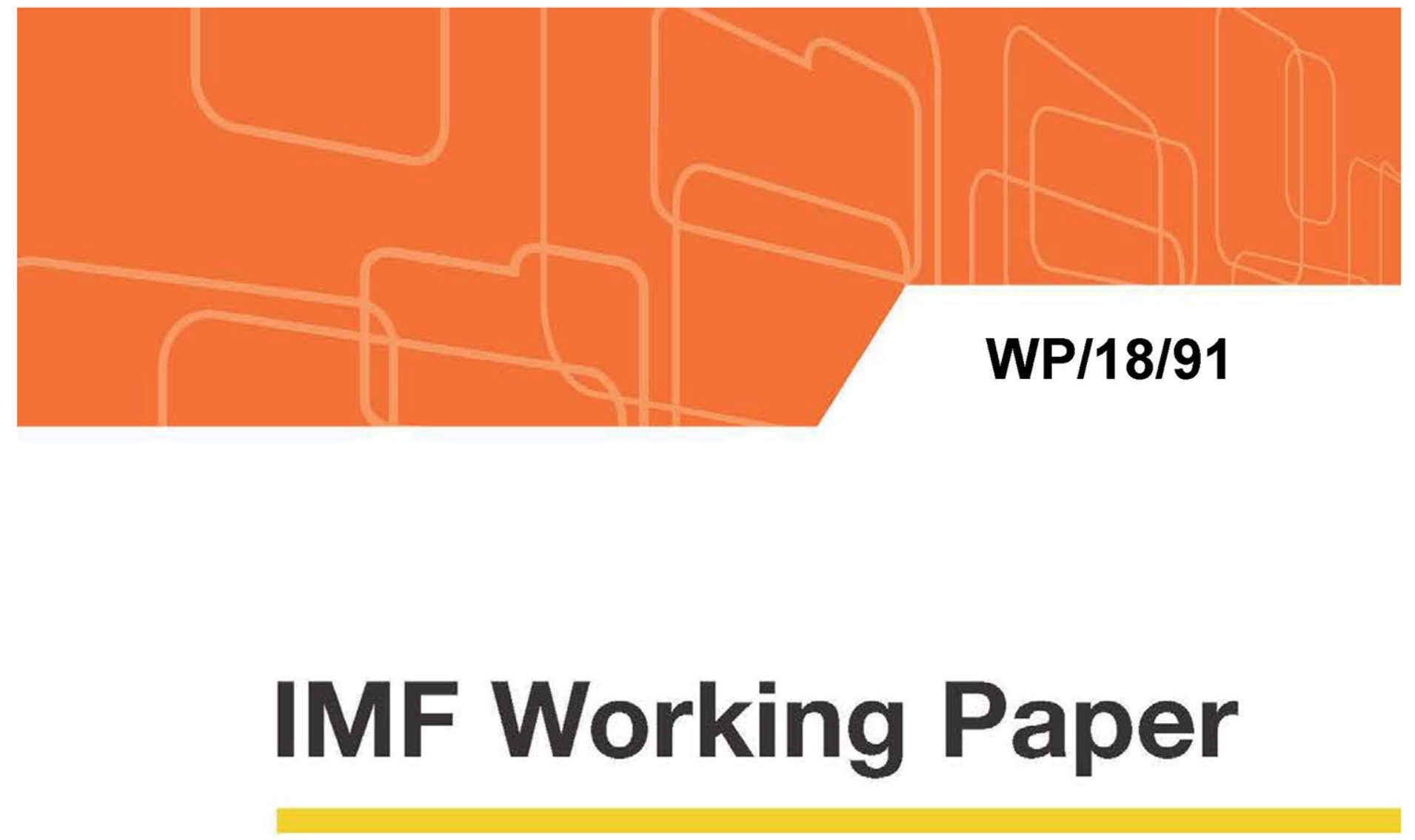

\title{
A New Strategy for Korea's Fiscal Policy in a Low Growth Environment
}

by Edda Zoli, Hou Wang, Douglas Laxton, Susanna Mursula, and Jiaxiong Yao

IMF Working Papers describe research in progress by the author(s) and are published to elicit comments and to encourage debate. The views expressed in IMF Working Papers are those of the author(s) and do not necessarily represent the views of the IMF, its Executive Board, or IMF management. 


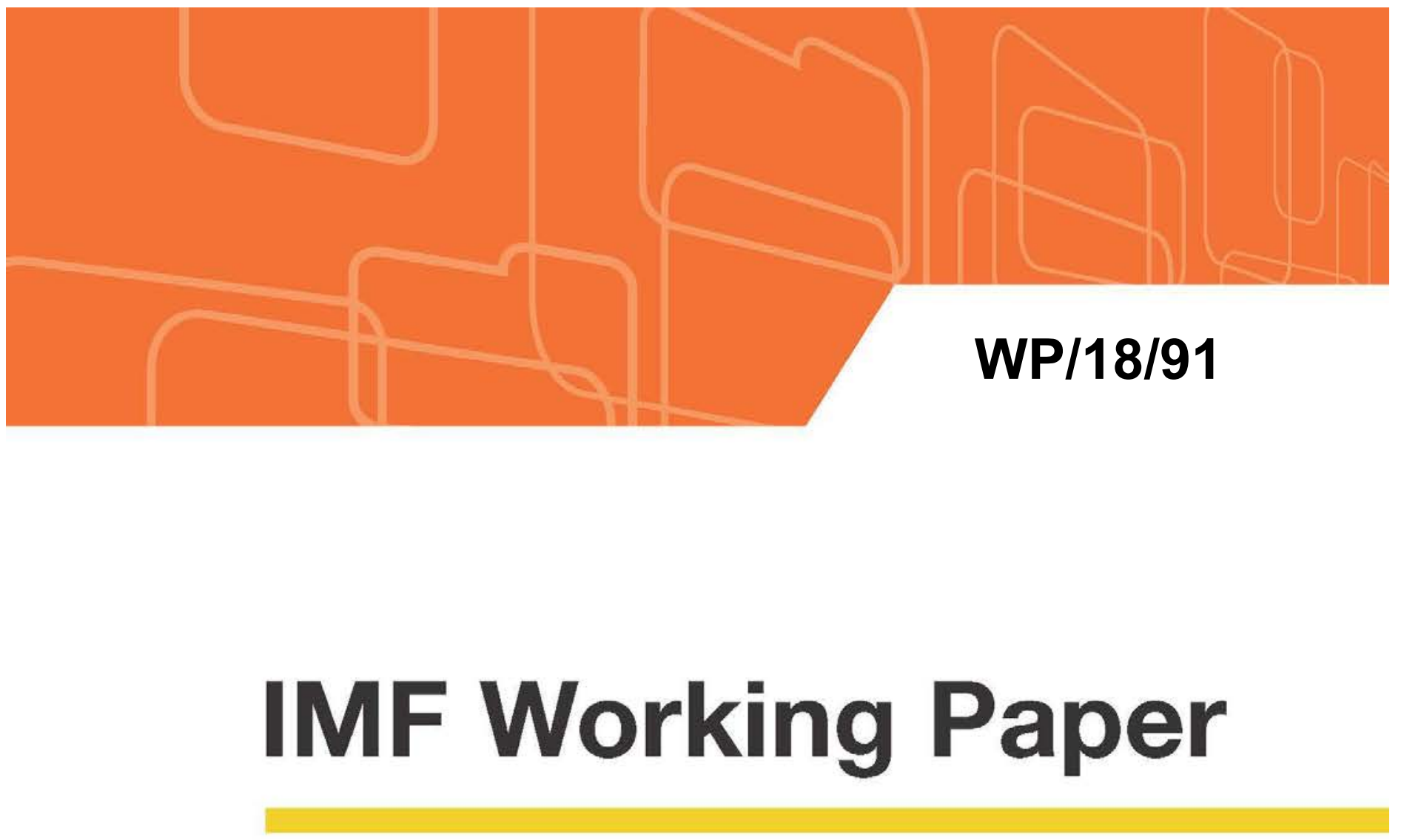

\section{A New Strategy for Korea's Fiscal Policy in a Low Growth Environment}

by Edda Zoli, Hou Wang, Douglas Laxton, Susanna Mursula, and Jiaxiong Yao

IMF Working Papers describe research in progress by the author(s) and are published to elicit comments and to encourage debate. The views expressed in IMF Working Papers are those of the author(s) and do not necessarily represent the views of the IMF, its Executive Board, or IMF management. 


\title{
IMF Working Paper
}

Asia and Pacific Department and Research Department

\section{A New Strategy for Korea's Fiscal Policy in a Low Growth Environment \\ Prepared by Edda Zoli, Hou Wang, Douglas Laxton, Susanna Mursula, and Jiaxiong Yao}

Authorized for distribution by Tarhan Feyzioglu and Douglas Laxton

April 2018

IMF Working Papers describe research in progress by the author(s) and are published to elicit comments and to encourage debate. The views expressed in IMF Working Papers are those of the author(s) and do not necessarily represent the views of the IMF, its Executive Board, or IMF management.

\begin{abstract}
Adverse demographics and other structural weaknesses impinge on Korea's long-term fiscal outlook and potential growth. Moreover, inadequate social protection is creating poverty and dampening consumption. The paper presents projections of Korea's fiscal outlook, using new estimates of potential growth obtained with a novel multivariate filter. It shows that keeping fiscal revenues-to-GDP constant would result in an explosive public debt dynamic in the long term. Then, through simulations of the Flexible System of Global Models, the paper analyzes policies to preserve fiscal sustainability, while boosting potential growth and social protection. It concludes that with greater revenue mobilization, Korea can stabilize debt-to-GDP well below "dangerous" levels. Policies to address Korea's challenges include higher targeted transfers to the most vulnerable and fiscal measures to support female labor force participation and employment, accompanied by product and labor market reforms.
\end{abstract}

JEL Classification Numbers: E12; E17; E62; H53; H55; H63

Keywords: aging; long-term fiscal sustainability; structural reforms; potential output

Author’s E-Mail Address: EZoli@imf.org; HWang2@imf.org; DLaxton@imf.org; SMursula@imf.org; JYao@imf.org 


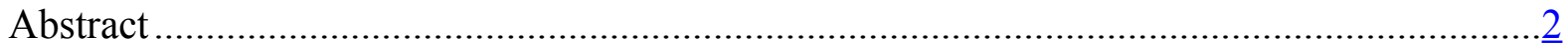

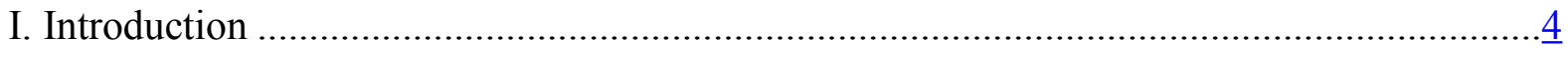

II. Assessing Korea's Potential Output with an Extended Multivariate Filter ........................ $\underline{5}$

III. The Fiscal Impact of Aging: Implications for Debt Sustainability .................................. $\underline{8}$

IV. Promoting Sustained, Inclusive and More Balanced Growth.....................................14

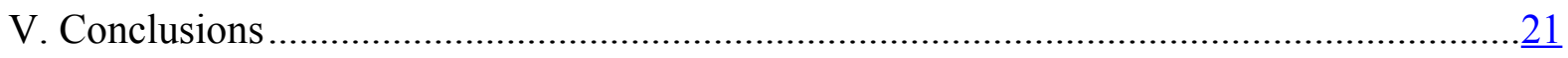

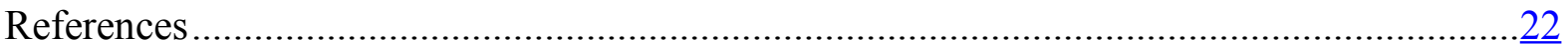

\section{Figures}

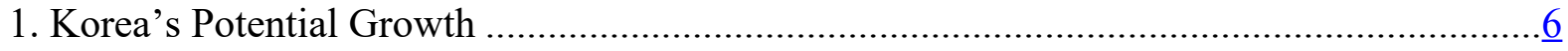

2. Korea's Employed Population .............................................................................

3. Ratio Between Korea and U.S. Productivity ............................................................ 7

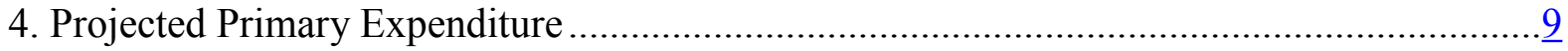

5. Real GDP and Real Interest Rate Assumptions ............................................................ 10

6. Increased Age-Related Spending with Unchanged Revenues .......................................12

7. Increased Age-Related Spending Financed by Higher Debt and Higher Revenues .............13

8. Permanent Increase in Social Safety Net Spending Financed by Tax Instruments .............16

9. Permanent Decrease in Saving Rate ...................................................................... 17

10. Combined Effect of Policies on Output, Consumption and the Current Account .............19

11. Combined Effect of Policies on Fiscal Variables .........................................................20

\section{Tables}

1. Average Annual Potential Growth .......................................................................

2. Pension and Healthcare Spending Projections......................................................... 9 


\section{INTRODUCTION}

Korea has an impressive track record of fiscal prudence that has been a key contributor to macroeconomic stability. With a general government debt at around 40 percent and an average fiscal surplus of the consolidated central government of 1.2 percent of GDP since 2010, Korea has one of the soundest fiscal positions among advanced economies.

Rapid population aging will have an adverse impact on the fiscal and growth outlook. With the old-age dependency ratio expected to rise by 50 percentage points in the next 50 years, pension and health-related public spending will increase by 10-16 percent of GDP by 2060 . Moreover, because of the decline in labor force growth, potential growth will slow down, thus worsening the dynamics of public debt to GDP ratio in the long term.

Other structural headwinds impinge on long-term growth. Productivity is lagging, especially in services, and there are several labor and product market distortions (OECD, 2016; Schauer, 2018). Because of all these structural issues, Korea faces the risk of settling into a "new mediocre" of more subdued long-term growth.

Moreover, insufficient social protection is contributing to worsening inequality. Public social spending is less than half the OECD average, and benefits to the most vulnerable as well as pensions are less generous than in many other OECD economies (OECD, 2016). Inadequate safety nets result in old-age poverty, boost private-sector precautionary savings, depress consumption and growth and contribute to the large current account surplus. Indeed, the personal saving rate has increased by 8 percentage points since the early 2000 s, while the share of private consumption to GDP has fallen by 6 percentage points.

Against this background, can fiscal policy preserve the sustainability of public finances in the face of rising age-related spending, while supporting higher, inclusive and more balanced long-term growth? This paper analyzes the policy strategies needed to deal with these challenges. First, it presents projections for Korea's fiscal outlook in the very long run, taking into account the expected increase in healthcare and pension spending, and using new estimates of potential growth - obtained with a novel multivariate filter. Then, through model simulations, the paper analyzes alternative policy options to preserve fiscal sustainability, boost potential output and mitigate income inequality.

The main results are as follows. As age-related spending will increase very significantly, a policy that attempted to keep total revenue fixed as a share of GDP would result in explosive debt dynamics. Hence, sizable increases in the revenues will be needed in the long run to stabilize debt.

Given Korea's low public debt and the low global interest rate environment, rising agerelated spending can be financed through a combination of higher revenues - obtained partly by broadening the tax base - and additional borrowing. When comparing alternative combinations of deficit and revenue financing that ensure debt sustainability, small revenue 
changes can have a quite a large impact on the debt dynamics. Overall, Korea can stabilize the debt to GDP ratio to levels well below what is considered a "dangerous" level, leaving enough fiscal space to implement policies to boost potential growth and social protection. These include higher targeted transfers to the most vulnerable and fiscal measures to support female labor force participation and employment, accompanied by comprehensive product and labor market reforms.

The structure of the paper is as follows. Section II provides an assessment of Korea's longrun potential growth using a novel multivariate filter approach. Section III and IV present the elements of a new strategy for Korea's fiscal policy in a low-growth environment, using illustrative model simulations. Section V concludes.

\section{Assessing Korea's Potential Output With an EXtended Multivariate Filter}

The long-term fiscal outlook depends critically on growth prospects. Estimates of potential output are important inputs into the fiscal — as well as monetary — policy formulation. Such estimates are used for aggregate demand management, as well as assessing the sustainable levels of taxes, expenditures and debt dynamics. Potential output is typically defined as the maximum level of output that an economy can sustain without generating inflationary pressure (Okun, 1962).

The standard multivariate filter augmented with a production function is used to assess both the level and the growth rate of potential output. ${ }^{1}$ Compared to previous work with multivariate filters (e.g., Alichi and others, 2015, 2017), this new approach is based on specifying a Cobb-Douglas production function as part of a multivariate system and then augmenting the list of observable variables to include data on employment, the capital stock, and total-factor productivity (TFP). TFP, which is calculated as the residual from the production function, provides a measure of how efficiently and intensively the factors of production are utilized. By assuming a certain path of Korea's productivity catch-up vis-à-vis the United States, one can project the equilibrium TFP. Equilibrium employment is estimated based on assumptions about future population growth (from the United Nations projections), the equilibrium participation rate, and the NAIRU. Combining equilibrium estimates of TFP and employment with estimates of the capital stock, one can obtain estimates of potential output.

This novel approach is in stark contrast to the standard production-function approach used in many policymaking institutions. In that traditional framework TFP and employment trends are separately estimated using the HP filter - the HP filter, being a univariate filter, ignores the links between economic variables and suffers from serious end-of-sample problems (Laxton and Tetlow, 1992). Estimates based on univariate filters like the HP filter are not

\footnotetext{
${ }^{1}$ See Laxton, Wang, Yao, and Zoli (2018, forthcoming) for the documentation of the methodology. Previous empirical estimates of Korea's potential growth are Jain-Chandra and Zhang (2014), IMF (2015a), and Zoli (2016).
} 
only inconsistent with the definition of potential output, but also suffer from significant uncertainty when the estimates are computed in real time (Alichi and others, 2017).

Korea's potential growth is projected to steadily fall until 2058 (Figure 1). Declining employment growth (and levels after 2030, see Figure 2), driven by a shrinking labor force population, explains most of this downward trend. ${ }^{2}$ The contribution from capital to potential growth is expected to fall over time to reach a constant capital-output ratio in the long run, after a period of a rapid rise in the capital-output ratio, partly explained by capital deepening in the Korean economy (Figure 3).

Figure 1. Korea's Potential Growth

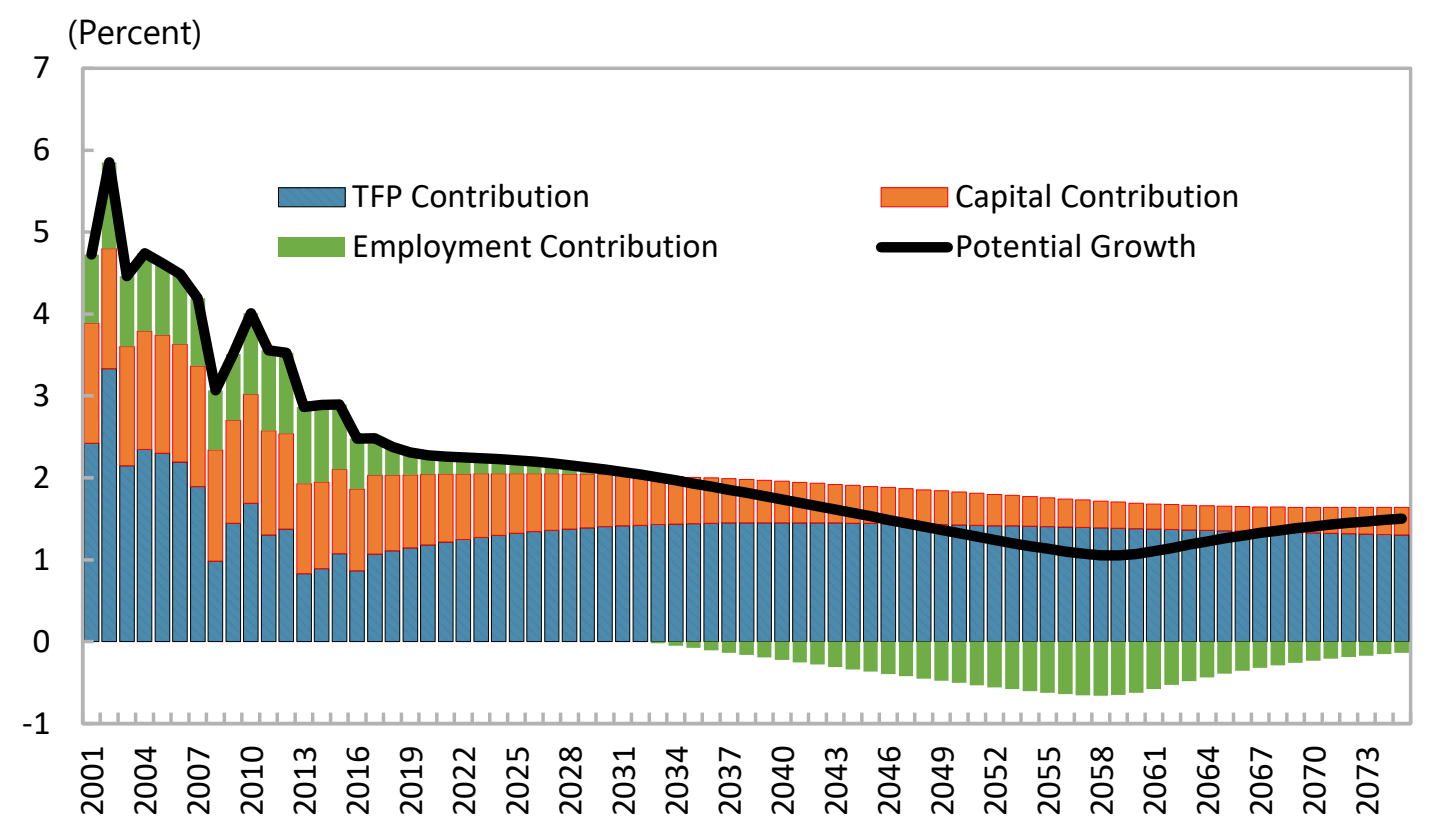

Source: WEO and authors' estimates.

\footnotetext{
${ }^{2}$ Employment $(N)$ can be decomposed into the labor force population $(M)$, the participation rate $(P)$, and the unemployment rate $(u): N=M P(1-u)$. The projection for employment is based on the following assumptions. For the labor force population, the projected population growth rate from the United Nations is used until 2060, and afterwards it is assumed that the growth rate converges gradually towards zero. The participation rate is assumed to stay at the current level of 63 percent. The unemployment rate is assumed to gradually return to 3.5 percent in the long run. These assumptions are in line with the range of historical values and based on current trends.
} 
Figure 2. Korea's Employed Population

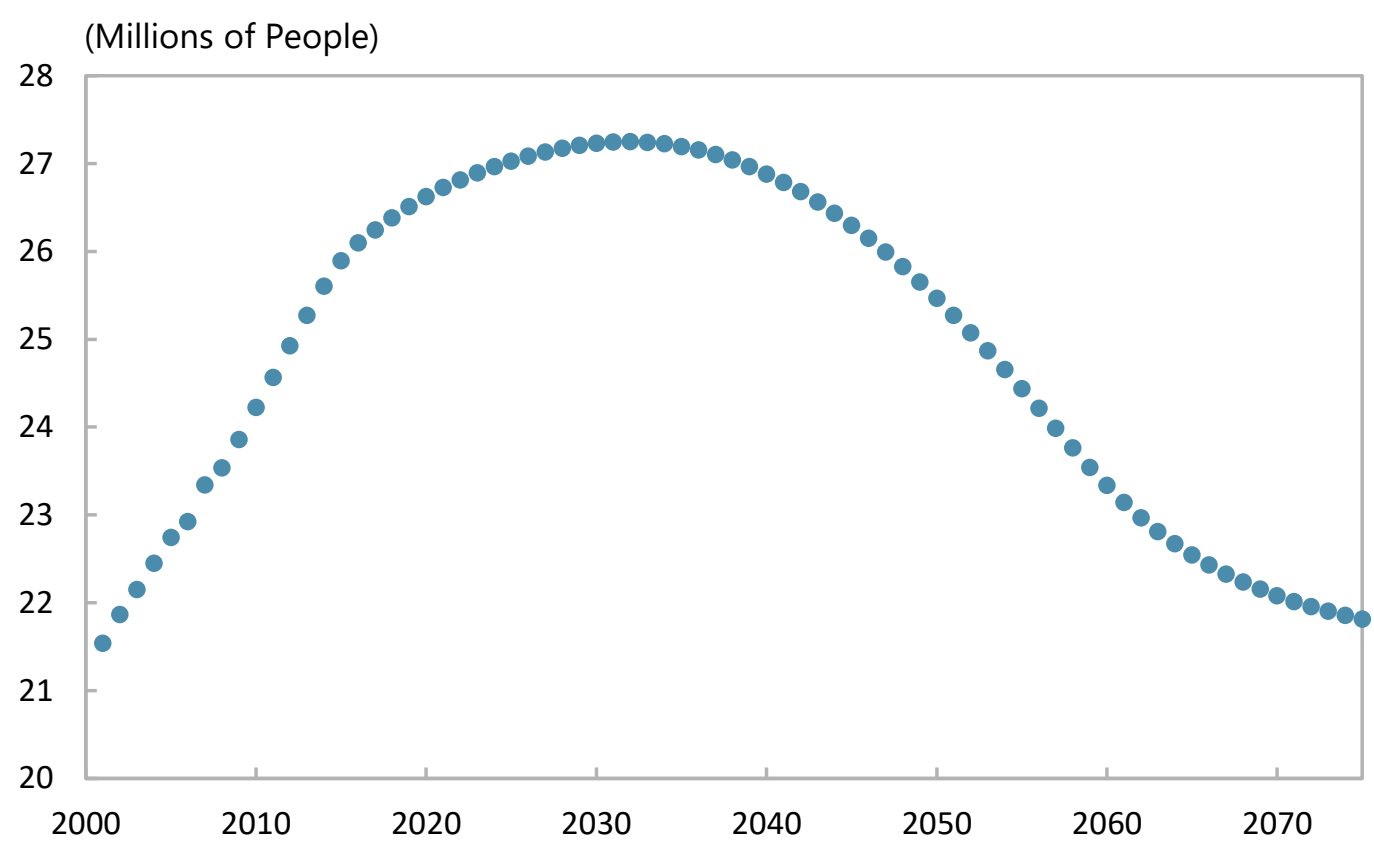

Source: WEO, United Nations, and authors' estimates.

Figure 3. Ratio Between Korea and U.S. Productivity

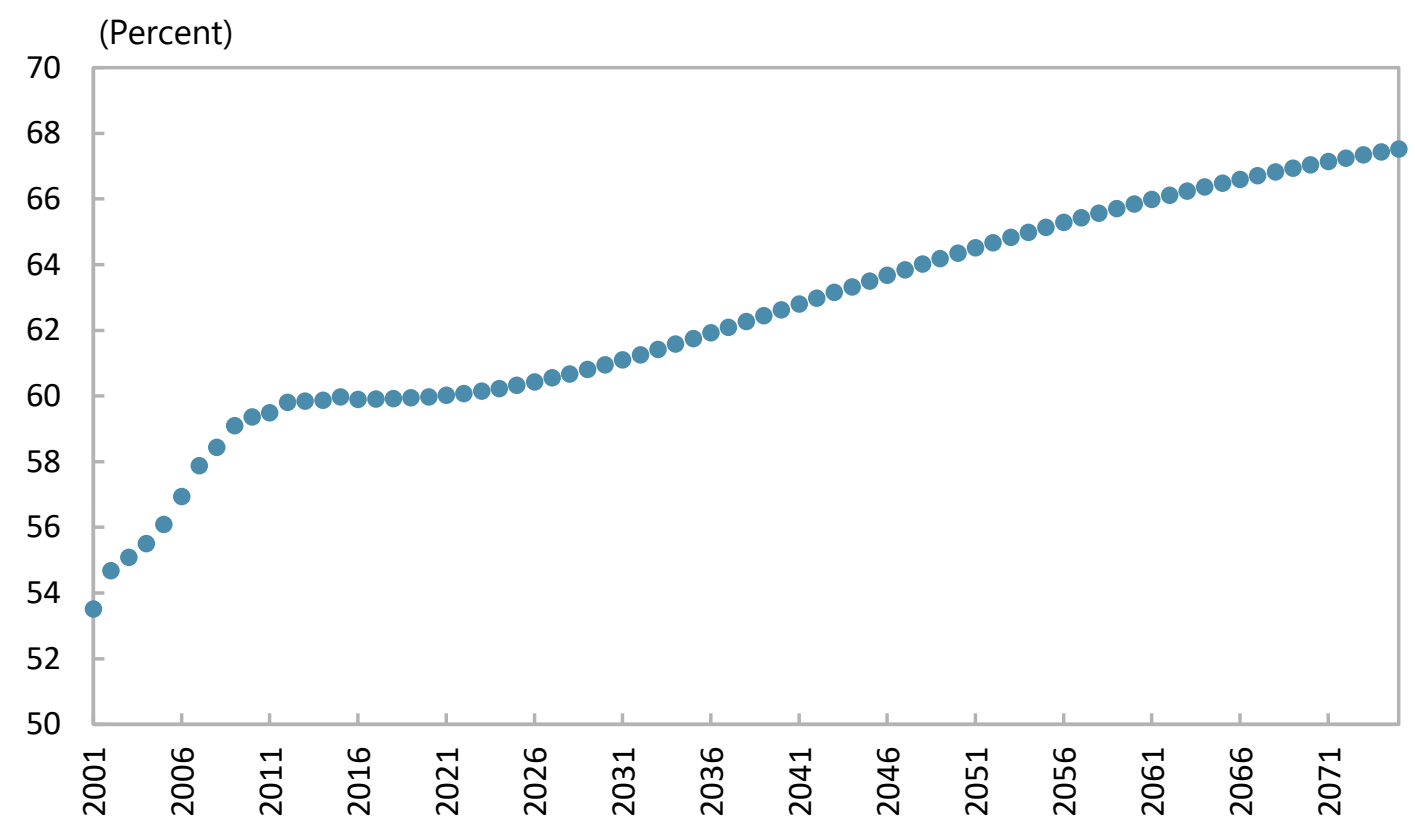

Source: WEO and authors' estimates.

CInternational Monetary Fund. Not for Redistribution 
The projections assume that productivity growth will pick up in about a decade, eventually resulting in a partial closing of the productivity gap vis-à-vis the U.S. in the long run. In the early 2000s Korea's productivity grew rapidly. Since the global financial crisis, a combination of domestic and global factors - both structural and cyclical - have resulted in a slow productivity growth in Korea as well as other Asian economies (IMF, 2017). Such weakness is assumed to persist for some time. Currently, Korea's total factor productivity is around 60 percent that of the U.S. (IMF, 2017). The long-run steady-state for the Korea-U.S. productivity ratio is projected at 68 percent, based on the assumptions that (i) Korea continues to converge to the technological frontier; and (ii) the speed of convergence is somewhat slower than the historical average of the past two decades.

With these assumptions, potential growth will gradually slow down to 1.2 percent. Our potential growth estimates are lower than those presented in the 2015 Ministry of Strategy and Finance (MOSF) report for the period 2020-30, but very similar afterwards (Table 1). It is important to emphasize that there is significant uncertainty in these estimates. For example, reliable and timely capital stock data can be hard to obtain, and the convergence of productivity across countries can be subject to structural shocks.

Table 1. Average Annual Potential Growth

\begin{tabular}{|l|c|c|c|c|}
\hline (in percent) & $\mathbf{2 0 2 0 - 3 0}$ & $\mathbf{2 0 3 0 - 4 0}$ & $\mathbf{2 0 4 0 - 5 0}$ & $\mathbf{2 0 5 0 - 6 0}$ \\
\hline $\begin{array}{l}\text { Authors' estimates } \\
\text { based on an extended } \\
\text { multivariate filter }\end{array}$ & 2.2 & 1.9 & 1.5 & 1.2 \\
\hline MOSF (2015) & 2.6 & 1.9 & 1.4 & 1.1 \\
\hline
\end{tabular}

Source: KDI and authors' estimates.

Potential growth is not policy invariant and certainly not a constant. Korea's potential growth could be raised through structural reforms to boost productivity and labor force participation. A comprehensive package of measures, supported by fiscal policy, is needed to boost growth on a sustainable basis.

\section{The FisCal ImPaCt OF AgIng: Implications FOR DebT SustainabiLITY}

Korea's public spending for pension and healthcare is expected to increase by about 10-16 percent of GDP by 2060 (Table 2). According to the projections of the MOSF and other Korean institutions, pension spending is set to rise by about 6-7.5 percent. Healthcare spending is expected to grow by about 5 to 9 percent, based on OECD 3 and IMF's recent estimates.

\footnotetext{
3 The OECD estimates are presented in De la Maisonneuve and Martins (2015). The projections range refer to future public healthcare and long-term care spending under two scenarios of cost containment (with implicit policy actions) and cost-pressure (without policy actions).
} 
Table 2. Pension and Healthcare Spending Projections

\begin{tabular}{|l|c|c|c|c|c|c|}
\hline (in percent of GDP) & $\begin{array}{c}\mathbf{2 0 1 5} \text { or } \\
\mathbf{2 0 1 6}\end{array}$ & $\mathbf{2 0 3 0}$ & $\mathbf{2 0 4 0}$ & $\mathbf{2 0 5 0}$ & $\mathbf{2 0 6 0}$ & $\begin{array}{c}\text { Change } \\
\mathbf{2 0 1 5 / 1 6} \\
\text { to 2060 }\end{array}$ \\
\hline \multicolumn{7}{|c|}{ Pension } \\
\hline MOSF (2015) & 3.0 & 5.2 & 7.2 & - & 10.6 & 7.5 \\
\hline $\begin{array}{l}\text { National Pension } \\
\text { Research Institute (2013) }\end{array}$ & 1.2 & 2.5 & 4.1 & 5.7 & 6.9 & 5.7 \\
\hline $\begin{array}{l}\text { National Assembly } \\
\text { Budget Office (2012) 1/ }\end{array}$ & 2.4 & 4.3 & 5.8 & 7.7 & 8.9 & 6.5 \\
\hline \multicolumn{7}{|c|}{ Health } \\
\hline MOSF (2015) 2/ $/ 4 / 4$ & 0.6 & 0.9 & 0.9 & & 0.8 & 0.2 \\
\hline OECD (2015) 3/4/ & 4.0 & - & - & - & $8.6-13.2$ & $4.6-9.2$ \\
\hline IMF (2016) 3/ & 4.4 & 6.1 & 7.6 & 9.0 & 10.0 & 5.6 \\
\hline
\end{tabular}

Note:1/ Estimated based on 2012 level and 2020 projection reported in National Assembly Budget Office (2012).

2/ Health insurance spending, including long-term care insurance.

3/ Health-care and long-term care.

4/ Estimates presented in De la Maisonneuve and Martins (2015)

Source: MOSF (2015); National Pension Research Institute (2013); National Assembly Budget Office (2012); De la Maisonneuve and Martins (2015).

This section presents scenarios for the long-term public debt outlook, taking into account the projected increase in age-related spending. In the scenarios, the projections of GDP growth are consistent with the October 2017 WEO forecast until 2022. From 2023 onwards output grows at its potential, as estimated in Section II. Annual primary expenditure as a share of GDP is assumed to increase by about 0.3 percentage point per year on average from 2023 through 2060, implying a cumulative increase of around 13 percentage points by 2060, the mid-point of the projected increase on pension and health-care spending (Figure 4).

Figure 4. Projected Primary Expenditure

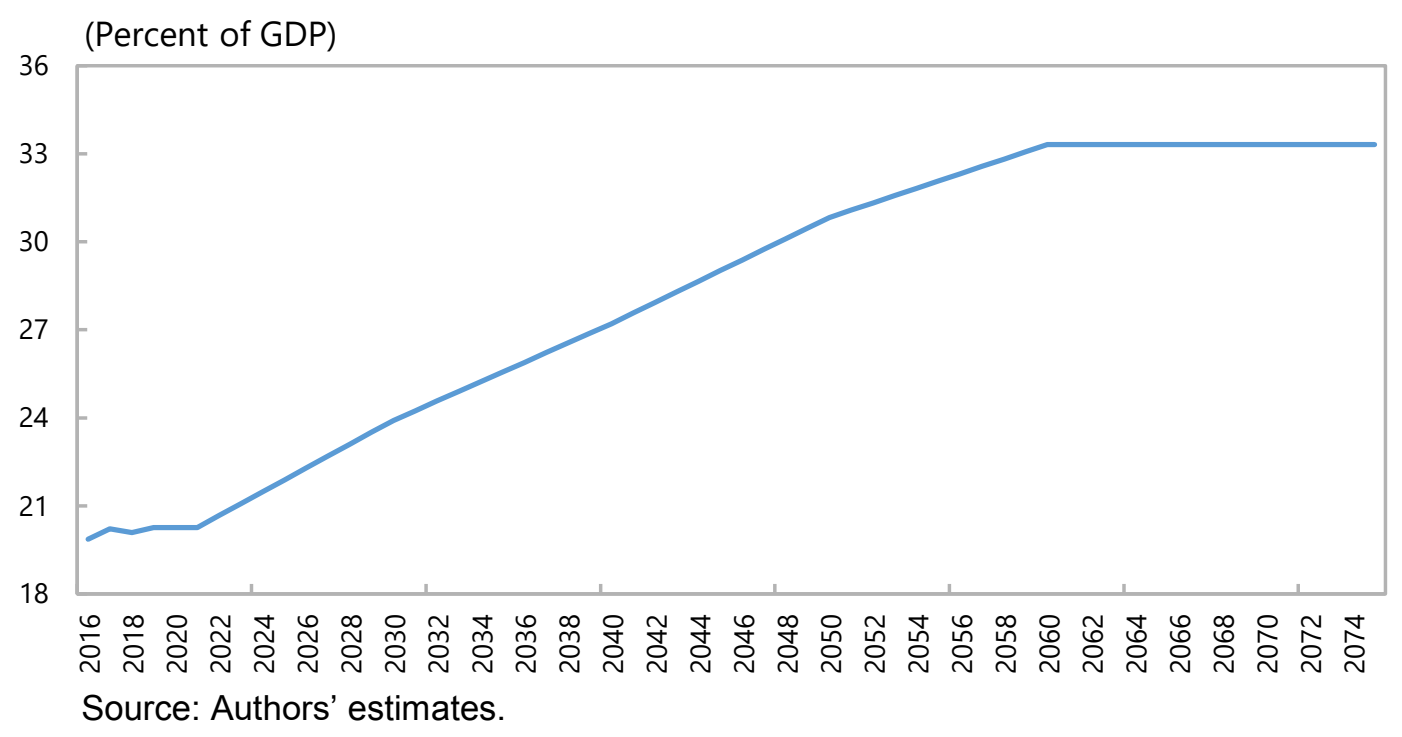


The nominal interest rate on government debt is assumed to be rising over time, as the global economy gradually exits a period of high world saving rates and exceptionally low interest rates (Figure 5). Demographic factors, such as aging, also put upward pressures on the domestic nominal interest rate, which is assumed to increase gradually to 4.5 percent in 2060 , at which point the old-dependency ratio is projected to peak. The 4.5 percent long-run interest rate on government debt embodies an approximately 50 bps country-risk premium relative to the United States, similar to the level we observed in recent years. Assuming the inflation rate at the 2 percent target, the real interest rate on government bonds increases above real GDP growth starting in 2035.

The assumption that the real interest rate is greater than the real growth rate of the economy is usually referred to as a no-ponzi-game condition. It is a standard assumption for prudent longer-term fiscal policy projections. If the world real interest rate were less than the growth rate of the economy, it would be in the interest of governments to increase debt to finance current expenditures. Effectively, there would be no cost to containing explosive levels of debt as new debt could always be issued to pay off old debt that is maturing. Other advanced economies have experienced periods of positive differential between the real interest rate and growth. ${ }^{4}$ The dynamics of the relationship between growth and the real interest rate is clearly subject to uncertainty. Growth-friendly fiscal policies, especially in a period of extremely low long-term interest rates, would help raise potential growth in a more sustainable way, to prepare for an eventual return of higher long-term interest rates.

Figure 5. Real GDP and Real Interest Rate Assumptions

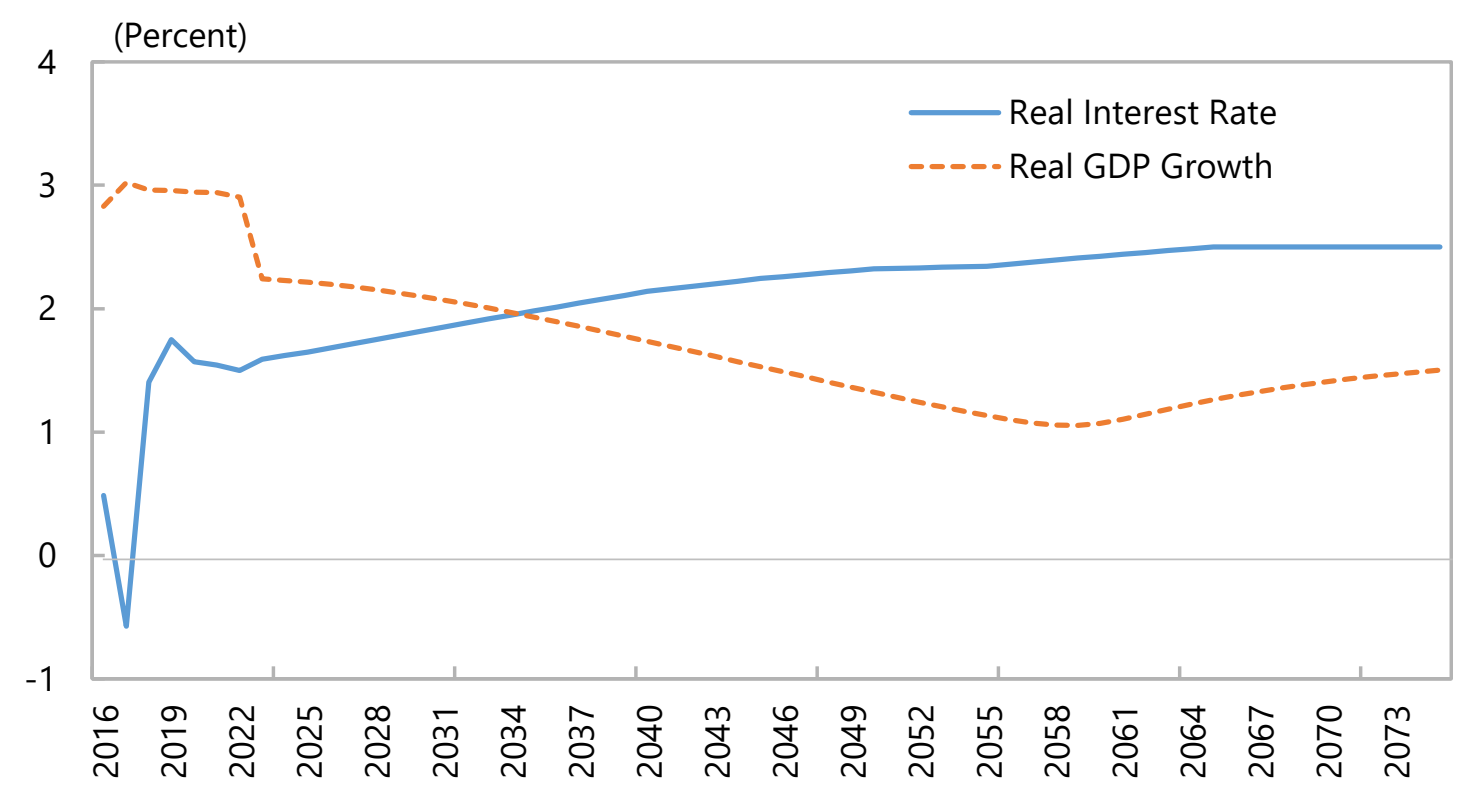

Source: Authors' estimates.

\footnotetext{
${ }^{4}$ For example, in the case of Japan, the real interest rate-real GDP growth differential has been unfavorable from the early 1990s to 2013. Only in the last few years we observe that Japan's real interest rate has stayed persistently below the real GDP growth, mainly due to ultra-loose domestic monetary policy.
} 


\section{Impact of Increased Age-Related Spending with Unchanged Revenues}

With the growing fiscal needs from age-related spending, a policy that attempted to keep total revenue fixed as a share of GDP would clearly result in explosive debt dynamics (Figure 6). ${ }^{5}$ In this scenario, the consolidated fiscal balance would turn negative in 2024 and reach a deficit of about 14 percent of GDP in 2050. The large and increasing deficits would result in a debt level over 100 percent of GDP by 2050, at which time age-related spending would continue to put upward pressure on deficits. Similarly, the National Assembly Budget Office (NABO, 2016) projects a deficit of the consolidated central government of about 8 percent of GDP and a debt to GDP ratio of 111 percent in 2050, assuming no change in policies. This upward pressure on primary deficits combined with an assumption that the real interest is greater than the real growth rate of the economy would result in explosive debt dynamics.

Sensitivity analysis confirms the key finding that, without revenues increases, the rise in agerelated spending would result in an explosive debt dynamic in the long term. For example, if the insurance premiums received by the National Health Insurance Service (NHIS) are added to government revenues, the debt-to-GDP ratio is projected to reach nearly 150 percent in 2060 and keep growing very rapidly afterwards. ${ }^{6}$ If potential growth were to follow the projections in MOSF (2015) as reported in Table 1, the debt ratio will only be marginally different in the long run (less than 1 percentage of GDP difference in 2075) from our baseline.

\footnotetext{
${ }^{5}$ With unchanged policies, future revenues-to-GDP ratio could even decline somewhat. According to NABO's (2016) projections, revenues to GDP ratio will drop by about 3 percentage points by 2060 as social security contributions decrease due the shrinking working age population, and the National Pension Fund returns fall as the fund starts depleting. The 2015 MOSF report projects revenues to GDP ratio to remain fairly stable between 2016 and 2060.

${ }^{6}$ The insurance premium income reported by the NHIS was 3.1 percent of GDP in 2016.
} 
Figure 6. Increased Age-Related Spending with Unchanged Revenues
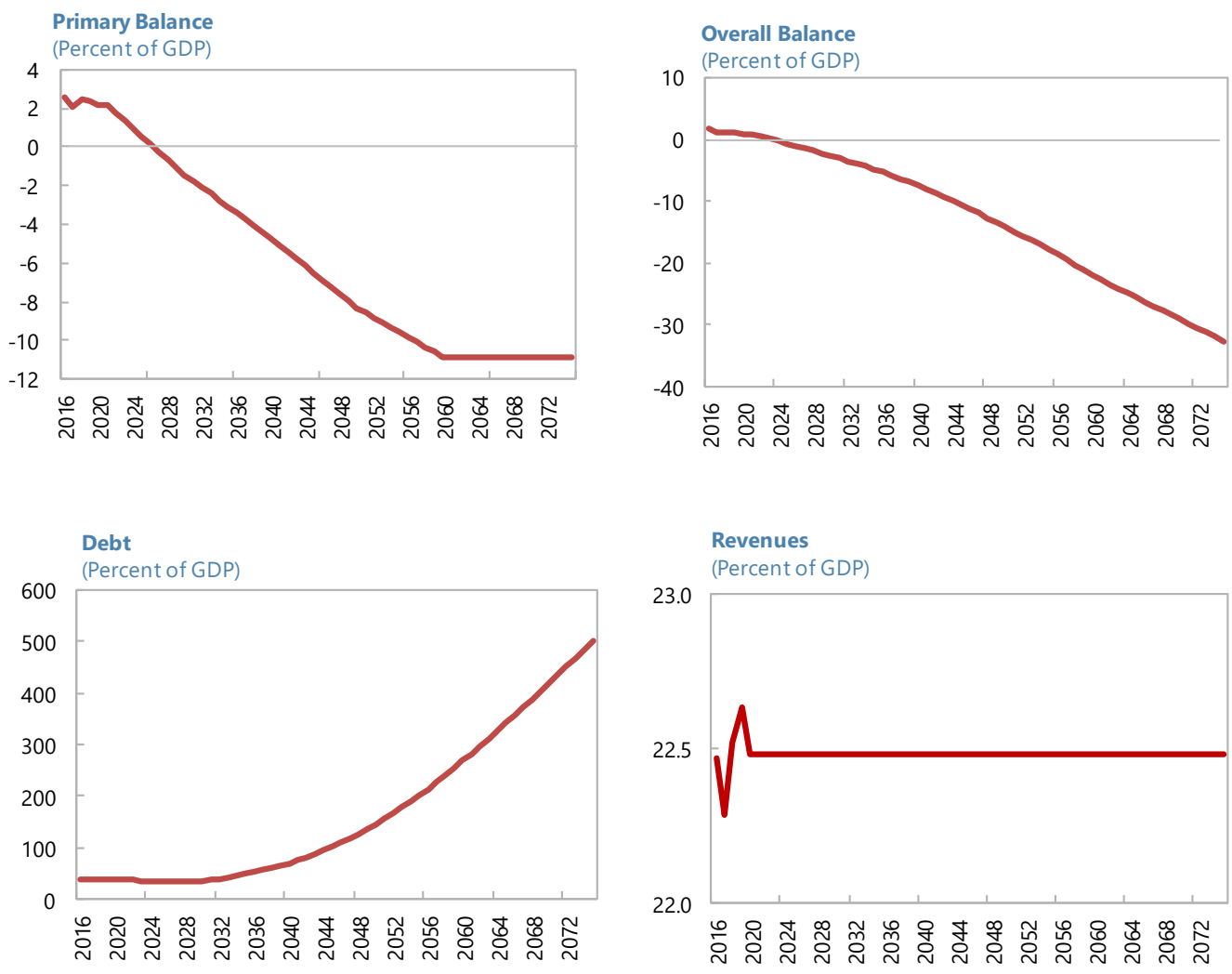

Source: Authors' estimates.

\section{Increased Age-Related Spending Financed by Debt and Higher Revenue}

A number of policy options can be considered to ensure long-term debt sustainability given the projected increases in age-related spending. They include:

- Contain long-term pension spending pressures by increasing the retirement ages in both the private and public sectors. ${ }^{7}$

- Increase revenues by broadening the tax base with both efficiency and equity gains (NABO, 2012; IMF, 2014a). ${ }^{8}$

\footnotetext{
7 The pension age is currently 61 with at least ten years of contributions, but a reduced early pension can be withdrawn from the age of 56 years. The normal pension age is gradually being increased, reaching 65 in 2033 and the early pension age will increase to 60. An additional hike in the retirement age by 3 years by 2035 would reduce pension spending by an estimated 1 percentage point of GDP in 2050.

${ }^{8}$ Korea's average effective personal income tax rate is one of the lowest in OECD, and for the median wage earner is close to zero. The base could be broadened by gradually eliminating the wage and other deductions. The corporate income tax is a source of multiple distortions that could be streamlined, in particular there is a
} 
- Increase payroll contribution rates that are currently very low, at 9 percent, compared to a 20 percent average in advanced economies.

- Increase selected tax rates, for example the VAT rate, which is currently at only 10 percent.

Given Korea's low public debt and the low global interest rate environment, rising agerelated spending could also be financed through borrowing. With government debt expected to remain around 40 percent of GDP for at least 15 years, Korea certainly has room to increase its debt-to-GDP ratio over the long term.

Korea can safely sustain public debt levels above 40 percent of GDP. Different approaches can be used to estimate the maximum debt for a given country, defined as the ceiling beyond which debt dynamics spiral out of control. IMF (2013) identifies such limit using the signal approach developed by Kaminsky and others (1998) as the level of the public debt that best predicts the occurrence of a debt distress event. Such benchmark is estimated to be 85 percent of GDP for advanced economies.

There are multiple paths that can ensure that Korea's public debt remains well below this debt threshold as aging-related spending increases. For instance, the debt to GDP ratio could be allowed to reach 45 percent of GDP in the long run, leaving enough space for policies to enhance social protection and support long-term growth. Figure 7 presents two illustrative paths involving different combinations of deficit and revenues financing. In both scenarios revenues are kept constant for 10 years; the fiscal surplus declines gradually and a deficit arises in 2024; the deficit peaks at about 1.5 percent of GDP in 2027. The debt-to-GDP ratio continues to decline until 2027, to about 30 percent. $^{9}$ Afterwards revenues start to increase. In the "permanent deficit" scenario, the deficit stabilizes at 1.5 percent of GDP. Debt reaches 40 percent of GDP in 2077 and achieves the steady state of 45 percent of GDP past beyond 2100. Revenues increase from 22 to 33 percent of GDP in 2060. In the "temporary deficit" scenario, revenues increase a bit faster, to reach nearly 34 percent of GDP in 2060; the deficit declines to zero in 2084. However, given the dynamics of the primary balance (which turns into a surplus in 2040), public debt-to-GDP ratio peaks at 30 percent in 2036 and declines afterwards. As the scenario illustrates, a slightly faster increase in revenues has a sizable impact on the debt-to-GDP ratio by affecting the primary balance and, hence, the overall debt dynamics.

\section{Figure 7. Increased Age-Related Spending Financed by Higher Debt and Higher Revenues}

need to move toward neutrality in taxing various sources of capital income. VAT could be extended, notably to all new real state supplies, including the value of land, insurance and financial services, and suppliers to exporters.

${ }^{9}$ The debt dynamics reflects also the assumption that fiscal surpluses are saved, so the decline in the debt-toGDP ratio during periods when the overall balance is positive is driven by the increase in nominal GDP. The assumption that surpluses are saved is consistent with current practice, and it is made also to avoid the projected debt-to-GDP ratio falling to levels that are unrealistically low. 

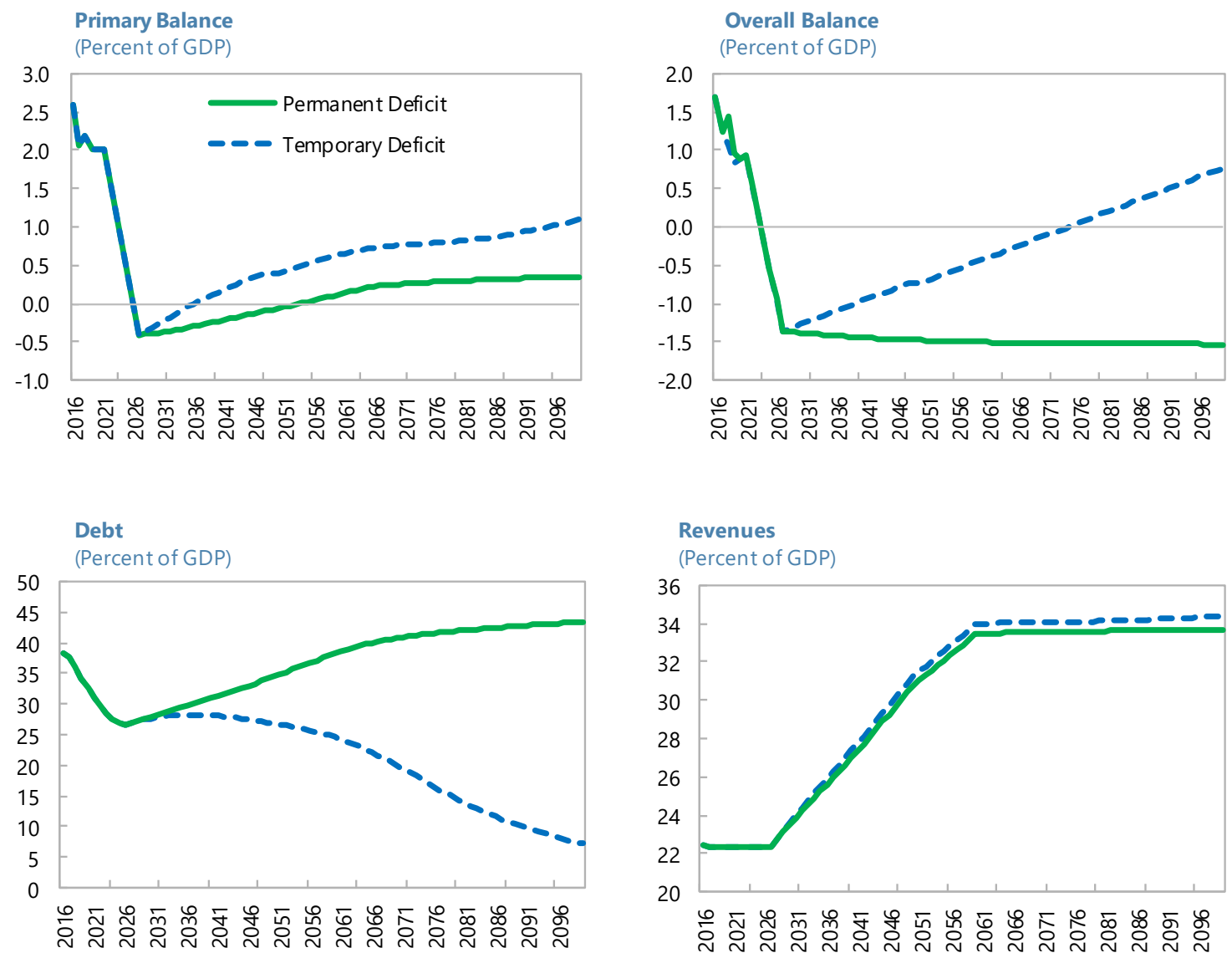

Source: Authors' estimates.

\section{Promoting Sustained, Inclusive and More Balanced Growth}

In addition to ensuring fiscal sustainability in the face of pressure from age-related spending, Korea also needs to address declining potential growth, inadequate social protection and external imbalances. To analyze the implications of alternative fiscal policy measures aimed at tackling these issues, simulations are carried out using the G20MOD module of the Flexible System of Global Models (FSGM) ${ }^{10}$ In these scenarios, fiscal policy is actively used to strengthen social safety nets and boost female labor force participation and employment. The simulations show the impact of different measures compared to the baseline, which assumes that a combination of higher revenues and borrowing would be used to finance the increase in age-related spending.

\footnotetext{
${ }^{10}$ Appendix I provides a broad summary of the G20MOD module. Andrle and others (2015) provide a complete description of the FSGM.
} 
The G20MOD module of FSGM used for the simulations is a multi-region, forward-looking, semi-structural global model consisting of the G20 countries and the rest of the world. The model includes various fiscal instruments, such as government investment, government consumption, transfers, and different types of taxes (capital, labor and consumption). The model features stock-flow consistency, where government deficits accumulate into higher levels of government debt and current account deficits accumulate into higher levels of net foreign debt. Unlike standard DSGE models, FSGM has a well-defined steady state where some countries are net creditors and others are net debtors. Given this structure it is possible to study the implications of a transition from one steady state to another where the government runs government deficits that permanently increase the government-debt-to-GDP ratio. The simulations will show the impact of policies relative to a baseline, which has to be formulated outside of the FSGM model. The projections in Figure 7 will be taken as baseline.

\section{Permanent Increase in Social Safety Net Spending}

Strengthening social protection would boost consumption-led growth and contribute to rebalancing the economy. Figure 8 illustrates the effects of a permanent increase in targeted transfers (transfers to liquidity-constrained consumers) of 0.75 percent of baseline GDP, financed by a gradual increase in either consumption, or labor income, or capital income taxes, as well as a rise in deficit by 0.8 percentage points of GDP. The consumption tax is the least harmful revenue source in terms of both its macroeconomic impact (low multiplier) and allocative distortions. Indeed, the increase in capital taxation would reduce investment, while an increase in labor income tax would lower employment, resulting in output loss compared to an increase in consumption taxes. Gradual and pre-announced increases in the consumption tax rate over time would avoid the abrupt intertemporal reallocations of consumption. In all three cases, government-debt-to-GDP ratio increases by 15 percentage points above the baseline in the very long run and stabilizes there. 
Figure 8. Permanent Increase in Social Safety Net Spending Financed by Difference Tax Instruments

(Deviation from Baseline)
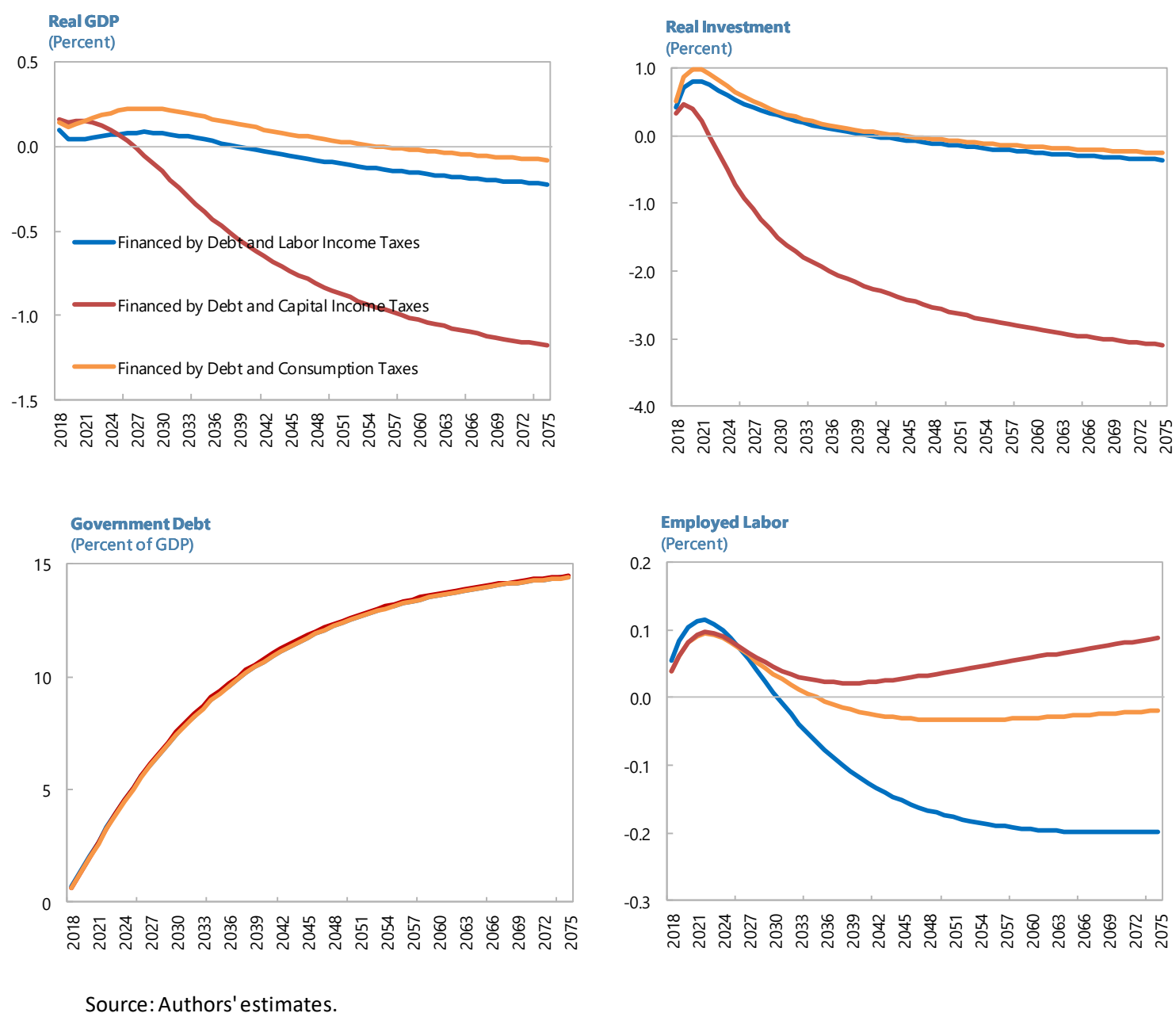

A stronger social safety net would also reduce income uncertainty and household precautionary saving. For example, OECD (2011) finds that an increase in public health care spending by 1 percent of GDP is associated with a decline in the saving rate by 1.9 percentage points. In the FSGM simulation, due to the impact of permanently higher transfers, private saving as a share of GDP declines by 1 percentage point in the long run, with stronger private consumption and investment boosting GDP growth and reducing Korea's current account surplus (Figure 9). The real exchange rate appreciates, consistent with stronger imports from the rest of the world. By helping the economy move towards an inclusive and consumption-led growth model, the underlying fiscal measures would lessen the economy's vulnerability in dealing with potential external shocks in the future. Such a policy would have a long-lasting, but not permanent impact on output and would need to be combined with policies that raise productivity growth and the labor supply. 
Figure 9. Permanent Decrease in Saving Rate

(Deviation from Baseline)
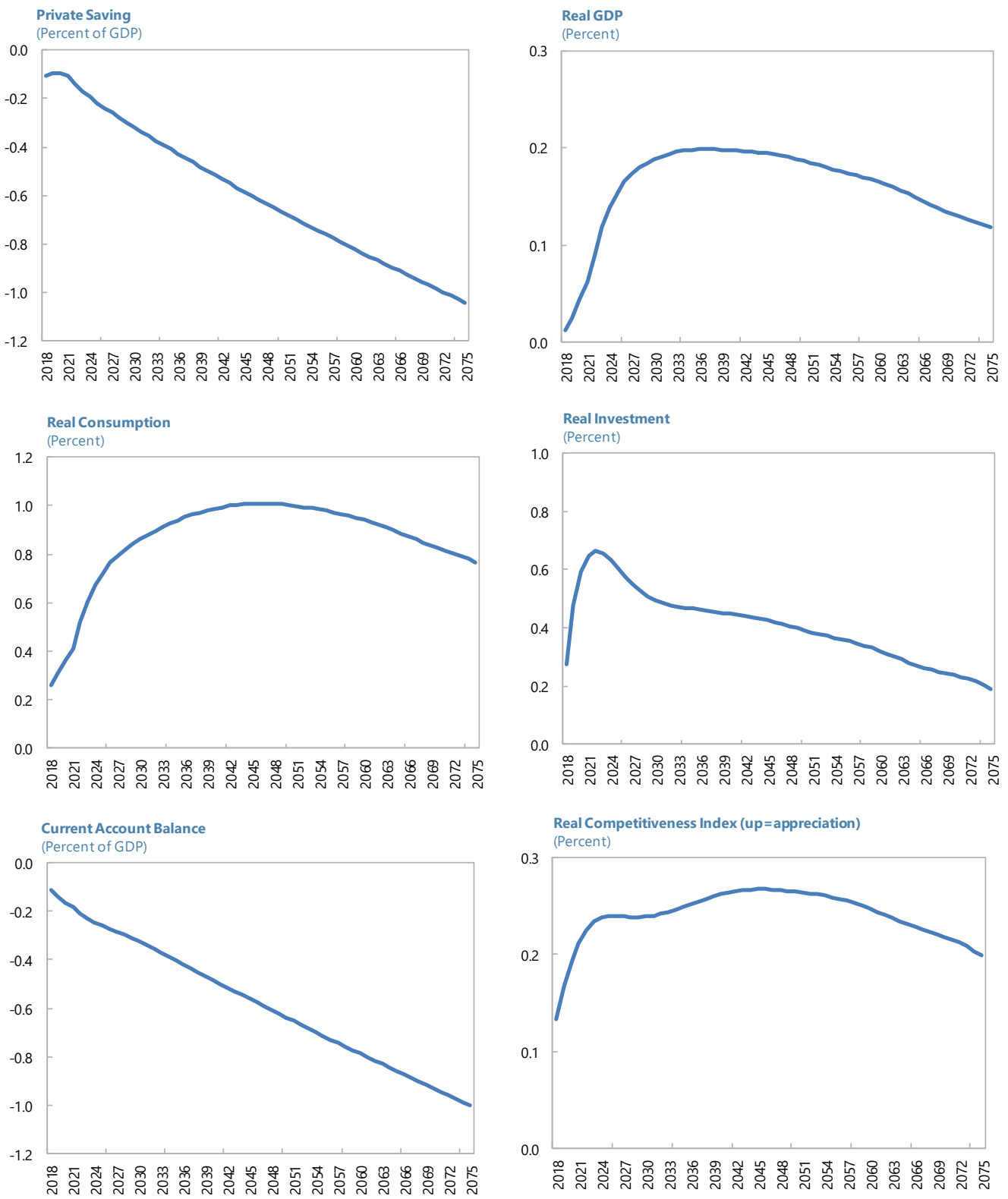

Source: Authors' estimates. 


\section{Structural Reforms and Fiscal Measures to Boost Labor Supply}

Potential growth can be boosted through structural reforms and fiscal measures. Fiscal policy can support long-term growth through different channels (IMF, 2014b, c, 2015b). Efficient public investment, especially in infrastructure, can raise the economy's productive capacity. Social benefits for specific groups (e.g., public spending for childcare and active labor market policies, ALMP) can have significant impact on labor supply, and hence, potential output. Government spending on research and development (R\&D) or tax incentives to encourage private R\&D can enhance productivity. Furthermore, fiscal policies can support labor and product market reforms that ultimately yield productivity gains by mitigating their distributive effects (Banerji and others, 2017). Moreover, rebalancing the tax structure away from direct taxes that fall on labor and capital and towards indirect taxes on consumption (VAT) and property taxes would improve allocative efficiency (Arnold and others, 2011; Ebrill and others, 2001).

Simulations are carried out to assess the impact of fiscal measures to boost labor supply and the efficiency of the tax structure, combined with structural reforms to strengthen productivity. The reform package includes: easing product market regulation and employment protection legislation ${ }^{11}$, raising the share of consumption and property taxes in total tax revenues, increasing childcare spending and, strengthening active labor market policies. ${ }^{12}$ The scenario assumes that Korea implements in 10 years 75 percent of the product market and employment protection reforms that would allow the country's regulation to converge to the average of the three OECD economies at the frontier. ${ }^{13}$ The share of consumption and property taxes in total tax revenues is assumed to increase by 1.1 percentage points, accompanied by a decline in the share of labor income tax that boosts labor force participation. Moreover, the scenario assumes an expansion in childcare spending by 0.25 percent of GDP, and an increase in ALMP spending by 0.5 percent of GDP, financed through a combination of higher VAT revenues and higher deficit. ${ }^{14}$

The simulation results indicate that with these reforms Korea's potential output could rise by more than 6 percent in the long run. On average, potential growth would increase by over 0.6 percentage point a year for a decade..$^{15}$ The additional spending on childcare and ALMP would result in a rise in public debt in the very long run of 15 percentage points of GDP.

\footnotetext{
${ }^{11}$ For an analysis of labor market rigidity in Korea, see Schauer (2017).

${ }^{12}$ A simulation involving increases in public spending on infrastructure is not carried out as Korea's infrastructure is already at the frontier (Corbacho and others, 2017). Appendix II contains the composition and cost of the illustrative structural reforms.

${ }^{13}$ Product market regulation is assessed using the OECD Product Market Regulation (PMR) index; the indicator of labor market regulation is the OECD Employment Protection Legislation (EPL) index. Estimates of the impact of easing regulation on productivity are based on Bassanini and Duval (2006) and Bouis and Duval (2011).

${ }^{14}$ The impact of childcare and ALMP spending on labor force participation and equilibrium employment is estimated using Bassanini and Duval (2006) and Bouis and Duval (2011).

${ }^{15}$ In the model the impact of an increase in spending on active labor market policies could be under estimated, as it is assumed to affect equilibrium employment, but does not have an impact on the participation rate.
} 


\section{Combined Effects of Policies}

The comprehensive policy package including stronger social safety nets, structural reforms, and an increase in fiscal spending to boost labor supply would yield multiple benefits. While supply-side reforms would improve the economy's competitiveness and its long-run growth, rebalancing the economy towards a more inclusive and consumption-driven growth model would be welfare-enhancing and reduce Korea's vulnerability to external shocks. Output and real consumption would increase by about 6 and 9 percent, respectively, in 10 years and the current account surplus would decline by nearly 2 percent of GDP in 10 years (Figure 10).

Figure 10. Combined Effect of Policies on Output, Consumption and the Current Account (Percent Deviation from Baseline)

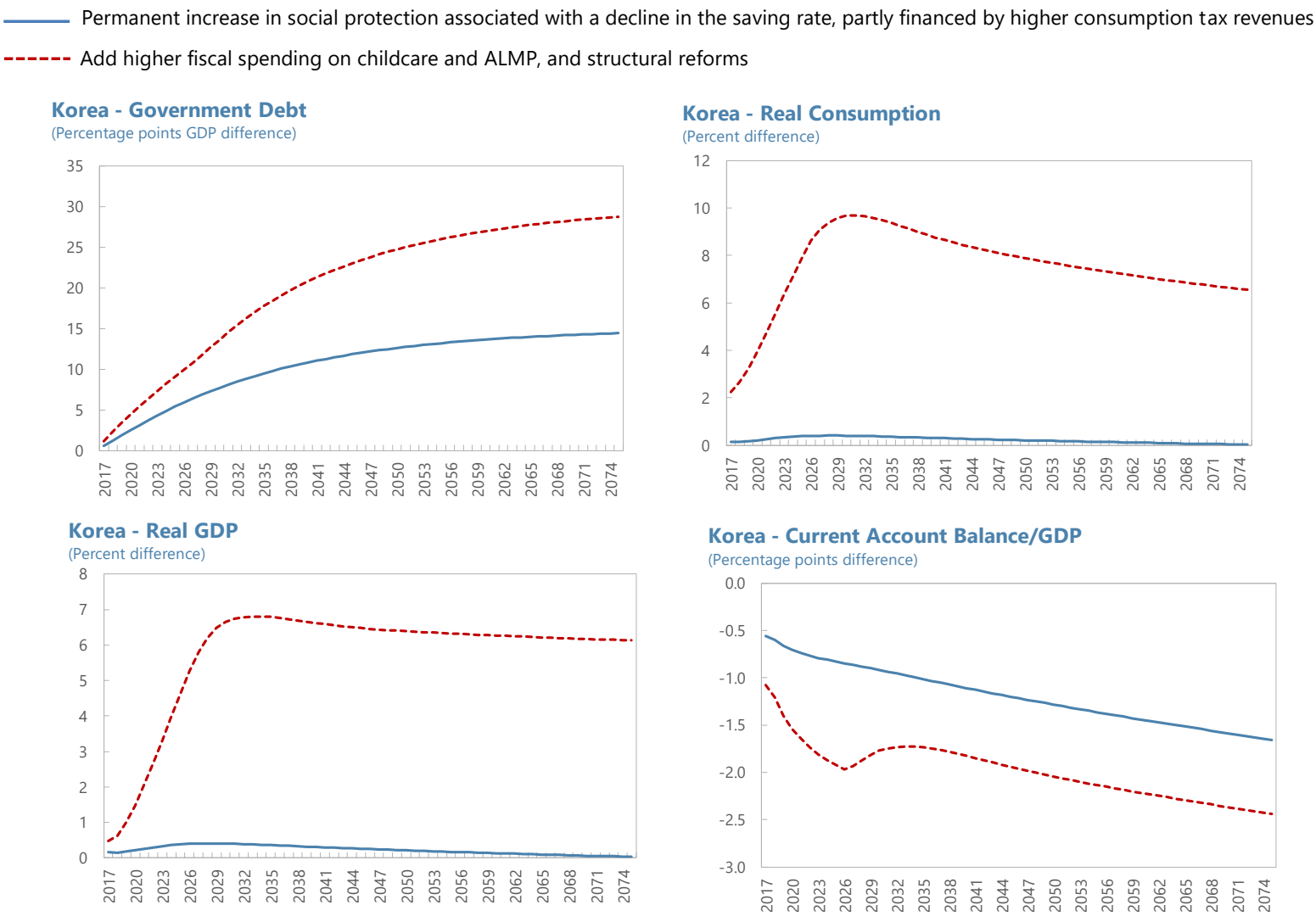

Source: Authors' estimates.

The policy package would imply a 30 percentage points increase in the debt ratio relative to the baseline scenario. Deficit would increase by 1.5 percentage points of GDP relative to the baselines. Assuming, for example, that the authorities decided to follow a path like the one depicted in the "temporary deficit" scenario of Figure 7, with the additional fiscal measures to boost social protection and labor supply, public debt-to-GDP would peak at 51 percent in 2061, and would decline afterwards (Figure 11). Deficit would peak at 3 percent of GDP in 2027 and decline afterwards. If, instead, the authorities decided to follow the "permanent deficit" scenario, public debt would reach 70 percent of GDP in 2080 and stabilize at 
75 percent past beyond 2100 . This level would still be well below the 85 percent benchmark for advanced economies. The deficit would stabilize at around 3 percent.

Figure 11. Combined Effect of Policies on Fiscal Variables (Percent Deviation from Baseline)
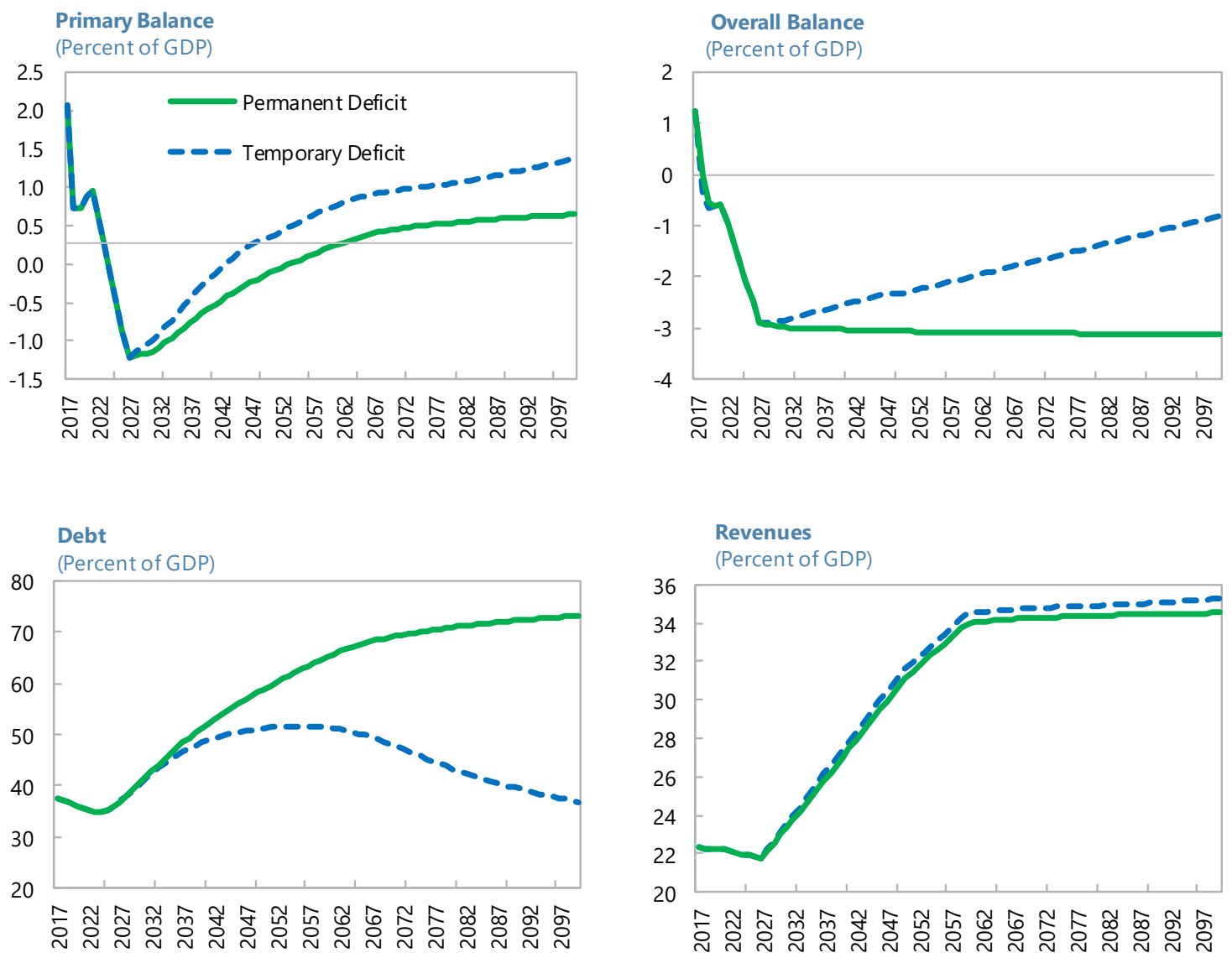

Sources: Authors' estimates.

Maintaining government debt at these levels would provide buffers to deal with the fiscal costs of possible reunification. Great uncertainty surrounds the timing and modalities of a possible future reunification, making estimates of possible fiscal costs difficult to pin down. The process of equalizing living standards would require a large increase in both public and private sector investment on physical and human capital (e.g., McKibbin and others, 2017), as well as increased welfare expenditure for North Korean residents (e.g., Auerbach, Chun, and Yoo, 2004). ${ }^{16}$ With careful and appropriate policy responses, the integration of the North Korean economy would also bring benefits to South Korea, including an increase in the labor force and higher potential growth over time.

\footnotetext{
${ }^{16}$ Estimates of the potential costs of reunification in Korea are wide ranging, reflecting different definitions of reunification costs, different methods, and different time horizons. They range from around 4 percent to 25 percent of South Korea's GDP each year for a decade (McKibbin and others, 2017; St. Brown, Choi, and Kim, 2012; Auerbach, Chun, and Yoo, 2004; Park, 1997).
} 


\section{Conclusions}

Rapidly aging population and other structural impediments impinge on Korea's long-term fiscal outlook and potential growth. Moreover, inadequate social protection is creating poverty, boosting precautionary savings, dampening consumption and contributing to external imbalances. Under current baseline assumptions, with rising age-related fiscal spending, a policy that kept fiscal revenue to GDP constant would result in an unsustainable path of public debt in the long term. Given Korea's low public debt, and low interest rates, it would be more desirable to finance the rising age-related with higher borrowing and additional revenues obtained by broadening the tax base and with selected tax increases. Overall, the size of government will need to rise.

To promote sustained, inclusive and more balanced growth, Korea needs to implement a comprehensive package of fiscal and structural measures. This would entail an increase in targeted social spending to help reduce poverty and bolster private consumption, as well as higher fiscal spending on childcare and active labor market policies to boost labor supply and, hence, potential growth. Structural reforms aimed at raising productivity growth and efficiency are also needed to raise potential growth and contribute to fiscal sustainability. Illustrative simulations indicate that even taking into account the projected increase in agerelated expenditure, higher spending on social safety nets, and fiscal measures to bolster labor supply, Korea can stabilize the debt-to-GDP ratio to levels well below the estimated dangerous threshold. 


\section{REFERENCES}

Andrle, M., P. Blagrave, P. Espaillat, K. Honjo, B. Hunt, M. Kortelainen, R. Lalonde, D. Laxton, E. Mavroeidi, D. Muir, S. Mursula, and S. Snudden, 2015, "The Flexible System of Global Models_-FSGM,” IMF Working Paper No. 15/64.

Alichi, A., O. Bizimana, S. Domit, E. Fernández-Corugedo, D. Laxton, K. Tanyeri, H. Wang, and F. Zhang, 2015, "Multivariate Filter Estimation of Potential Output for the Euro Area and the United States," IMF Working Paper No. 15/253.

- O. Bizimana, D. Laxton, K. Tanyeri, H. Wang, J. Yao, and F. Zhang, 2017, "Multivariate Filter Estimation of Potential Output for the United States," IMF Working Paper No. 17/106.

Arnold J., B. Brys, C. Heady, A. Johansson, C. Scwellnus, and L. Vertia, 2011, "Tax Policy for Economic Recovery and Growth,” Economic Journal 121: 1006-36.

Auerbach. A., Y. Chun, and I. Yoo, 2004, "The Fiscal Burden of Korean Reunification: A General Accounting Approach,” NBER Working Paper Series No. 10693.

Banerji, A., V. Crispolti, E. Dabla-Norris, R. Duval, C. Ebeke, D. Furceri, T. Komatsuzaki, and T. Poghosyan, 2017, "Labor and Product Market Reforms in Advanced Economies: Fiscal Costs, Gains, and Support," IMF Staff Discussion Note 17/03 (Washington, D.C.: International Monetary Fund).

Bassanini, A., and R. Duval, 2006, "Employment Patterns in OECD Countries: Reassessing the Role of Policies and Institutions," OECD Economics Department Working Paper No. 486 (Paris: OECD Publishing).

Bouis, R., and R. Duval, 2011, "Raising Potential Growth After the Crisis: A Quantitative Assessment of the Potential Gains from Various Structural Reforms in the OECD Area and Beyond," OECD Economics Department Working Paper No. 835 (Paris: OECD Publishing).

Corbacho A., D. Muir, M. Nozaki and E. Zoli, 2017, "the New Mediocre in Asia: What Can Fiscal Policy Do?", Paper presented at the IMF-BOF-PIIE conference "Prospects and Challenges for Sustained Growth in Asia", Seoul, September.

De la Maisonneuve, C. and J. O. Martins, 2015, “The Future of Health and Long-Term Care Spending”, OECD Journal: Economic Studies, Volume 2014.

Ebrill, L., M. Keen, J.-P. Bodin, and V. Summers, 2001, “The Modern VAT,” International Monetary Fund.

International Monetary Fund, 2013, Staff Guidance Note for Public Debt Sustainability, http://www.imf.org/external/pubs/ft/dsa/mac.htm 
, 2014a, Staff Report Republic of Korea: Staff Report for the 2013 Article IV Consultation, Country Report No. 14/101.

, 2014b, "Chapter 3: Is It Time for an Infrastructure Push? The Macroeconomic Effects of Public Investment." World Economic Outlook, October 2014 (Washington D.C.: International Monetary Fund).

October. , 2014c, “Can Fiscal Policy Do More for Jobs?”, Chapter 2 of Fiscal Monitor, _ 2015a, "Where are we Headed? Global Perspective on Potential Growth," in World Economic Outlook (Chapter 3), Washington, International Monetary Fund.

— , 2015b, "Fiscal Policy and Long-Term Growth,” IMF Policy Paper, June.

_ 2017, "The 'New Mediocre' and the Outlook for Productivity in Asia," Asia and Pacific Regional Economic Outlook, April.

Jain-Chandra, S. and L. Zhang, 2014, "How Can Korea Boost Potential Output to Ensure Continued Income Convergence?” IMF Working Paper No. 14/54.

Kaminsky, G., S. Lizondo, and C. Reinhart, 1998, "Leading Indicators of Currency Crisis", IMF Staff Papers, Vol. 45 (1), March.

Laxton, D. and R. Tetlow, 1992, "A Simple Multivariate Filter for the Measurement of Potential Output,” Technical Report No. 59, (Ottawa: Bank of Canada), June.

, H. Wang, J. Yao, and E. Zoli, 2018, "Multivariate Filter Estimation of Potential Output with Production Function: The Case of Korea," IMF Working Paper (forthcoming).

McKibbin, W., J. Lee, W. L, and C. Song, 2017, "Modelling the Economic Impacts of Korean Unification," CAMA Working Papers 2017-30.

Ministry of Strategy and Finance, 2015, "2016-2060 Long-term Fiscal Projections." http://www.mosf.go.kr/nw/nes/detailNesDtaView.do? searchBbsId1=MOSFBBS_000 $000000028 \&$ searchNttId $1=$ OLD_4096802\&menuNo $=4010100$

National Assembly Budget Office, 2012, “2012-2060 Long-Term Economic Outlook and Fiscal Analysis."

— , 2016, "2012-2060 Long-Term Economic Outlook and Fiscal Analysis.”

National Pension Research Institute, 2013, "A Summary of the 2013 Actuarial Projection Result." 
Okun, A.M., 1962, "Potential GNP: Its Measurement and Significance," in Proceedings of the Business and Economic Statistics Section, pp. 98-104.

OECD, 2011, “The Impact of Structural Reforms on Current Account Imbalances", OECD Economics Department Policy Notes, No. 3.

$\longrightarrow$, 2016, OECD Economic Surveys: Korea.

Park, T. 1997, "Projection of Korean Reunification Cost and Fund Raising Method," Chapter VIII of Jun, Hong-Taek and Young-Sun Lee eds., Strategies for Economic Integration after Korean Reunification, Research Report, Korea Development Institute.

Schauer, J., 2018, “Labor Market Duality in Korea,” International Monetary Fund, (forthcoming).

St. Brown, M., S. Choi, and H. Kim, 2012, "Korean Economic Integration: Prospects and Pitfalls," International Economic Journal, 26: 471-485.

Zoli, E., 2016, “Korea's Challenges Ahead-Lessons from Japan Experience,” IMF Working Paper No. 17/2. 


\section{Appendix I. A Summary of the IMF's G20MOD Module of FSGM}

G20MOD is an annual, multi-economy, forward-looking, model of the global economy combining both micro-founded and reduced-form formulations of economic sectors. G20MOD contains individual blocks for the G-20 countries, and 5 additional regions to cover the remaining countries in the world. The key features of a typical G20MOD country model are outlined below.

Consumption and investment have microeconomic foundations. Specifically, consumption features overlapping-generations households that can save and smooth consumption, and liquidity-constrained households that must consume all of their current income every period. Firms' investment is determined by a Tobin's Q model. Firms are net borrowers and their risk premia rise during periods of excess capacity, when the output gap is negative, and fall during booms, when the output gap is positive. This mimics, for example, the effect of falling/rising real debt burdens.

Trade is pinned down by reduced-form equations. They are a function of a competitiveness indicator and domestic or foreign demand. The competitiveness indicator improves one-forone with domestic prices - there is no local-market pricing.

Potential output is endogenous. It is modeled by a Cobb-Douglas production function with exogenous trend total factor productivity (TFP), but endogenous capital and labor.

Consumer price and wage inflation are modeled by reduced form Phillips' curves. They include weights on a lag and a lead of inflation and a weight on the output gap. Consumer price inflation also has a weight on the real effective exchange rate and second-round effects from food and oil prices.

Monetary policy is governed by an interest rate reaction function. For most countries, it is an inflation-forecast-based rule working to achieve a long-run inflation target.

There are three commodities in the model—oil, metals, and food. This allows for a distinction between headline and core consumer price inflation, and provides richer analysis of the macroeconomic differences between commodity-exporting and importing regions. The demand for commodities is driven by the world demand and is relatively price inelastic in the short run due to limited substitutability of the commodity classes considered. The supply of commodities is also price inelastic in the short run. Countries can trade in commodities, and households consume food and oil explicitly, allowing for the distinction between headline and core CPI inflation. All have global real prices determined by a global output gap (only a short-run effect), the overall level of global demand, and global production of the commodity question.

Commodities can function as a moderator of business cycle fluctuations. In times of excess aggregate demand, the upward pressure on commodities prices from sluggish adjustment in commodity supply relative to demand will put some downward pressure on demand. 
Similarly, if there is excess supply, falling commodities prices will ameliorate the deterioration.

Countries are largely distinguished from one another in G20MOD by their unique parameterizations. Each economy in the model is structurally identical (except for commodities), but with different key steady-state ratios and different behavioral parameters. 


\section{Appendix II. Composition and Cost of Illustrative Structural Reforms}

\begin{tabular}{|c|c|c|c|c|c|}
\hline Item & $\begin{array}{l}\text { OECD Typical } \\
\text { Historical } \\
\text { Reform Size }\end{array}$ & $\begin{array}{l}\text { OCED Illustrative Supply- } \\
\text { Side Impact after } 5 \text { Years }\end{array}$ & $\begin{array}{l}\text { Assumed Korean } \\
\text { Reform Size }\end{array}$ & Assumed Fiscal Cost & $\begin{array}{l}\text { Effects as } \\
\text { Implemented in } \\
\text { the Model }\end{array}$ \\
\hline $\begin{array}{l}\text { Product } \\
\text { Market } \\
\text { Regulation } \\
\text { Reform }\end{array}$ & $\begin{array}{l}20 \% \text { Reduction in } \\
\text { the OECD } \\
\text { Product Market } \\
\text { Regulation } \\
\text { (PMR) Index }\end{array}$ & $\begin{array}{l}\text { 2.4\% Level Gain in Multi- } \\
\text { Factor Productivity (MFP) } \\
\text { for Advanced Economies; } \\
\text { 3.4\% Level Gain in MFP for } \\
\text { Emerging Markets }\end{array}$ & $\begin{array}{l}22.5 \% \text { Reduction } \\
\text { in the OECD } \\
\text { PMR Index }\end{array}$ & None & $\begin{array}{l}2.7 \% \text { Level Gain } \\
\text { in MFP }\end{array}$ \\
\hline $\begin{array}{l}\text { Employment } \\
\text { Protection } \\
\text { Legislation } \\
\text { Reform }\end{array}$ & $\begin{array}{l}20 \% \text { Reduction in } \\
\text { the OECD } \\
\text { Employment } \\
\text { Protection } \\
\text { Legislation (EPL) } \\
\text { Index }\end{array}$ & $\begin{array}{l}\text { 0.44\% Level Gain in Labor } \\
\text { Productivity (LP) for } \\
\text { Advanced Economies; } \\
0.48 \% \text { Level Gain in LP for } \\
\text { Emerging Markets }\end{array}$ & $\begin{array}{l}30 \% \text { Reduction in } \\
\text { the OECD EPL } \\
\text { Index }\end{array}$ & None & $\begin{array}{l}0.66 \% \text { Level } \\
\text { Gain in LP }\end{array}$ \\
\hline $\begin{array}{l}\text { Tax } \\
\text { Structure } \\
\text { Reform }\end{array}$ & $\begin{array}{l}3 \text { Percentage } \\
\text { Point Rise in the } \\
\text { Share of } \\
\text { Consumption and } \\
\text { Property Taxes in } \\
\text { Total Tax } \\
\text { Revenues }\end{array}$ & $0.75 \%$ Level Increase in LP & $\begin{array}{l}\text { 1.125 Percentage } \\
\text { Point Rise in the } \\
\text { Share of } \\
\text { Consumption and } \\
\text { Property Taxes in } \\
\text { Total Tax } \\
\text { Revenues }\end{array}$ & None & $\begin{array}{l}0.28 \% \text { Level } \\
\text { Gain in LP }\end{array}$ \\
\hline $\begin{array}{l}\text { Spending on } \\
\text { Childcare }\end{array}$ & $\begin{array}{l}\text { 1 Dollar Increase } \\
\text { in Spending per } \\
\text { Child (in US\$ } \\
\text { PPP) }\end{array}$ & $\begin{array}{l}0.002 \text { Percentage Point } \\
\text { Increase in the Employment } \\
\text { Rate of Women }\end{array}$ & $\begin{array}{l}0.25 \% \text { of GDP, or } \\
\text { Approximately } \\
2000 \text { Dollar } \\
\text { Increase in } \\
\text { Spending per } \\
\text { Child (in US\$ } \\
\text { PPP) }\end{array}$ & $\begin{array}{l}\text { Targeted Transfers of } \\
0.25 \% \text { of GDP } \\
\text { Permanently, Financed } \\
\text { by VAT, Resulting in } \\
\text { a Rise in Debt of } 5 \\
\text { Percent of GDP in the } \\
\text { Long Run }\end{array}$ & $\begin{array}{l}0.75 \text { Percentage } \\
\text { Point Increase in } \\
\text { the Total Labor } \\
\text { Participation } \\
\text { Rate }\end{array}$ \\
\hline $\begin{array}{l}\text { Spending on } \\
\text { Active } \\
\text { Labor } \\
\text { Market } \\
\text { Policies }\end{array}$ & $\begin{array}{l}12.5 \text { Increase in } \\
\text { Spending per } \\
\text { Unemployed, as a } \\
\text { Percent of GDP } \\
\text { over Population }\end{array}$ & $\begin{array}{l}0.25 \text { Percentage Point } \\
\text { Decline in the Structural } \\
\text { Unemployment Rate } \\
\text { (NAIRU) }\end{array}$ & $\begin{array}{l}0.50 \% \text { of GDP, or } \\
\text { Approximately an } \\
\text { Increase of } 28 \text { in } \\
\text { Spending per } \\
\text { Unemployment, } \\
\text { as a Percent of } \\
\text { GDP over } \\
\text { Population }\end{array}$ & $\begin{array}{l}\text { Government } \\
\text { Consumption of } 0.50 \% \\
\text { of GDP Permanently, } \\
\text { Financed by VAT, } \\
\text { Resulting in a Rise in } \\
\text { Debt of } 10 \text { Percent of } \\
\text { GDP in the Long Run }\end{array}$ & $\begin{array}{l}0.56 \text { Percentage } \\
\text { Point Decline in } \\
\text { the NAIRU }\end{array}$ \\
\hline
\end{tabular}

Source: Bassanini and Duval (2006), Bouis and Duval (2011), authors' calculation. 